\title{
WPŁYW ZASADY SŁUSZNOŚCI NA KSZTAŁTOWANIE REGUŁ OKREŚLAJACYCH WYNAGRODZENIA CZŁONKÓW ORGANÓW SPÓŁEK AKCYJNYCH (WYBRANE ZAGADNIENIA)
}

1. Wynagrodzenia członków organów spółek akcyjnych są jednym z najbardziej kontrowersyjnych zagadnień $\mathrm{w}$ obrocie gospodarczym. ${ }^{1}$ Kwestia wynagrodzeń jest o tyle kontrowersyjna, że z jednej strony regulacje korporacyjne powinny sprzyjać odpowiedniemu wynagradzaniu członków organów spółki tak, aby pozyskać optymalnie wykwalifikowane osoby i zmotywować je do działania w interesie spółki. ${ }^{2}$ $\mathrm{Z}$ drugiej strony, należy przeciwdziałać nadmiernemu uposażeniu menadżerów, które nie jest zależne od nakładu pracy i jej efektów ekonomicznych. ${ }^{3}$ System wynagrodzeń może być przyczyną poważnych konfliktów w spółce między jej menadżerami a akcjonariuszami, w tym akcjonariuszami mniejszościowymi, którzy mają mniejszy wpływ na obsadę organów spółki. ${ }^{4}$

2. Analizując przepisy ustawy z dnia 15 września 2000 r. Kodeks spółek handlowych ${ }^{5}$ odnoszące się do wynagrodzenia członków zarządu i rady nadzorczej spółki akcyjnej prima facie nasuwa się wniosek, że przepisy k.s.h. są w tym zakresie fragmentaryczne. W odniesieniu do członków zarządu przepis art. 378 § 1 k.s.h. stanowi,

$1 \quad$ Wpływa niewątpliwie na to sytuacja gospodarcza, ponieważ właśnie w nadmiernie wygórowanych wynagrodzeniach członków organów spółek (zwłaszcza z sektora finansowego), które dodatkowo nie były powiązane z wynikiem finansowym, upatruje się jednego ze źródeł kryzysu w 2007 r. Zob. m.in. P. Gregg, S. Jewell, I. Tonks, Executive Pay and Performance: Did Bankers' Bonuses Cause the Crisis?, „International Review of Finance” 2012, nr 12, s. 93 i n.; G. Kirkpatrick, The Corporate Governance Lessons from the Financial Crisis, „Financial Market Trends" 2009, t. 1, s. 12 i n., http://www.oecd.org/daf/ca/corporategovernanceprinciples/42229620.pdf A. Opalski, Europejskie prawo spółek. Zasady europejskiego prawa spółek i ich wpływ na polskie prawo spółek, Warszawa 2010, s. 342.

3 J Gordon, Executive Compensation: If there's a Problem, What's the Remedy? The Case for Compensation Disclosure and Analysis, „Journal of Corporation Law” 2005, s. 675; B. Cheffins, R.S. Thomas, Should shareholders have a greater say over executive pay?, „Journal of Corporate Law Studies” 2001, Nr 1, s. 277.

4 G.A. Ferrarini, N. Moloney, Executive Remuneration in the EU: The Context for Reform, „ECGI - Law Working Paper" 2005, Nr 32, s. 5 i n.

5 T. jedn.: Dz.U. 2013, poz. 1030 ze zm.; dalej jako: k.s.h. 
że wynagrodzenie ${ }^{6}$ członków tego organu, zatrudnionych na podstawie umowy o pracę lub innej umowy, ustala rada nadzorcza, chyba że statut stanowi inaczej. ${ }^{7}$ Dodatkowo przepis $\S 2$ tego artykułu przewiduje, że walne zgromadzenie może upoważnić radę nadzorczą do ustalenia, iż wynagrodzenie członków zarządu obejmuje również prawo do określonego udziału w zysku rocznym spółki, który jest przeznaczony do podziału między akcjonariuszy zgodnie z art. $347 \S 1$ k.s.h. Natomiast w przypadku członków rady nadzorczej przepisy k.s.h. nie przesądzają, że w każdym przypadku przysługuje im wynagrodzenie. ${ }^{8}$ Przepis art. $392 \S 1$ zd. 1 k.s.h. stanowi, że „członkom rady nadzorczej może zostać przyznane wynagrodzenie”. 9 Wynagrodzenie członkom rady nadzorczej przysługuje, jeżeli przewiduje to statut lub uchwała walnego zgromadzenia. ${ }^{10}$ Zatem członkowie rady nadzorczej mogą, ale nie muszą otrzymywać wynagrodzenia. ${ }^{11}$ Odmiennie jest w przypadku, gdy członkowie rady nadzorczej zostali delegowani do indywidualnego wykonywania czynności nadzorczych. ${ }^{12}$ Na podstawie art. $390 § 3$ k.s.h. otrzymują oni ,osobne wynagrodze-

Warto zauważyć, że zdaniem M. Bieniaka w statucie spółki można zawrzeć „postanowienie, że pełnienie funkcji członka zarządu ma charakter honorowy i członkowie zarządu nie otrzymują z tego tytułu żadnego wynagrodzenia" (M. Bieniak, (w:) J. Bieniak, M. Bieniak G. Nita-Jagielski, K. Oplustil, R. Pabis, A. Rachwał, M. Spyra, G. Suliński, M. Tofel, R. Zabłocki, Kodeks spółek handlowych. Komentarz, Warszawa 2012, s. 1184).

Kompetencje do określenia wynagrodzenia członków zarządu mogą przysługiwać np. walnemu zgromadzeniu, akcjonariuszowi większościowemu lub grupie akcjonariuszy. Jednakże niedopuszczalne byłoby przyznanie takiego uprawnienia samemu zarządowi, tak: W. Popiołek, (w:) J. Strzępka (red.), Kodeks spółek handlowych. Komentarz, wyd. 5, Warszawa 2012, s. 965-967; A. Szumański, (w:) S. Sołtysiński, A. Szajkowski, A. Szumański, J. Szwaja, Kodeks spółek handlowych. Komentarz, t. III, Warszawa 2013, s. 673.

Dodatkowo przepis art. $392 \S 2$ k.s.h. przewiduje, że wynagrodzenie członków rady nadzorczej w formie prawa udziału w zysku spółki za dany rok obrotowy, przeznaczonego do podziału między akcjonariuszy zgodnie z art. $347 \S 1$ k.s.h., może uchwalić tylko walne zgromadzenie. Przy czym obejmuje ono tantiemę liczoną od zysku spółki przeznaczonego uchwałą zwyczajnego walnego zgromadzenia do podziału między akcjonariuszy, a nie od całego zysku spółki (W. Popiołek, (w:) J. Strzępka (red.), Kodeks spółek handlowych..., op. cit., s. 995).

J. Bieniak, (w:) J. Bieniak, M. Bieniak G. Nita-Jagielski, K. Oplustil, R. Pabis, A. Rachwał, M. Spyra, G. Suliński, M. Tofel, R. Zabłocki, Kodeks spółek kapitałowych. Komentarz, op. cit., s. 1203; W. Popiołek, (w:) J. Strzępka (red.), Kodeks spółek handlowych, op. cit., s. 995; J. Szwaja, B. Mika, (w:) S. Sołtysiński, A. Szajkowski, A. Szumański, J. Szwaja, Kodeks spółek handlowych. Komentarz, t. III, Warszawa 2013, s. 827. Zob. wyrok SN z 3.11.2009 r., II CSK 181/09, LEX nr 560018.

11 Jednakże nawet w przypadku, gdy członkowie rady nadzorczej nie otrzymują wynagrodzenia, to zgodnie z przepisem art. $392 \S 3$ k.s.h., przysługuje im zwrot kosztów związanych z udziałem w pracach rady. W wyroku z dnia 2 grudnia 2004 r. (III SA/Wa 116/04, Legalis) WSA w Warszawie stwierdził, że „zapis art. 392 ksh., wyraźnie rozgranicza otrzymane przez członka rady nadzorczej wartości pieniężne na wynagrodzenie i zwrot kosztów związanych z udziałem w pracach rady. To uprawnia do stwierdzenia, że zwrot kosztów z art. $392 \S 3$ ksh. nie stanowi elementu wynagrodzenia, a tym samym nie stanowi przysporzenia majątkowego po stronie członka rady nadzorczej. (...)".

12 W orzecznictwie sporna jest kwestia, czy osobne wynagrodzenie przewidziane w art. 390 § 3 k.s.h. dla delegowanego członka rady nadzorczej może przysługiwać tylko członkowi delegowanemu zgodnie z postanowieniami art. $390 \S 2$ k.s.h., a więc wówczas, gdy rada nadzorcza została wybrana w drodze głosowania oddzielnymi grupami i grupa delegowała członka rady nadzorczej do stałego wykonywania czynności nadzorczych, czy także w sytuacji, gdy źródłem ich delegacji jest uchwała rady nadzorczej na podstawie art. 390 § 1 k.s.h. W wyroku z dnia 27 listopada 2003 r. (IV CK 218/02, Legalis) SN orzekł, że „przewidziane w art. 390 § 3 ksh. osobne wynagrodzenie przysługiwać może jedynie członkowi rady nadzorczej delegowanemu do stałego indywidualnego wykonywania czynności nadzorczych na podstawie art. $390 \S 2 \mathrm{KSH}$ ". Analogiczne stanowisko zaprezentował SN w wyroku z dnia 9 lutego 2005 r., III CK 301/04, Legalis. Jednakże w wyroku z dnia 3 listopada 2009 r. (II CSK 181/09, Legalis) SN trafnie orzekł, że „osobne wynagrodzenia, o jakim mowa w $§ 3$ powoływanego przepisu odnosi się do obu grup członków rady nadzorczej, a więc również do takich, których źródłem delegacji jest uchwała rady nadzorczej (art. $390 \S 1$ k.s.h.). Skoro bowiem przyznanie osobnego wynagrodzenia uregulowane zostało w osobnej jednostce redakcyjnej, jednostka ta może być odnoszona zarówno do § 2, jak i § 1 przepisu". Szerzej P. Pinior, Problematyka wynagradzania członków rady nadzorczej w spółce akcyjnej, „Prawo Spółek” 2007, nr 7-8, s. 31 i n. 
nie, którego wysokość ustala walne zgromadzenie” lub „walne zgromadzenie może powierzyć to uprawnienie radzie nadzorczej (art. $390 § 3$ zd. 2 k.s.h.).

$\mathrm{Z}$ powyżej przedstawionych przepisów k.s.h. wynika, że nie zostały w nich oznaczone szczegółowe reguły dotyczące określania polityki spółki akcyjnej w zakresie wynagrodzeń. Zatem spółce przysługuje szeroka autonomia w zakresie kształtowania systemu wynagrodzeń członków jej organów. Wynagrodzenie członka zarządu i rady nadzorczej może być określane, co do zasady, dowolnie zarówno odnośnie sposobu ustalania jego struktury, jak i wysokości. W wyroku z dnia 14 lutego 2012 r., I ACa 1391/11 SA we Wrocławiu stwierdził, że ,art. 392 § 1 ksh. mówi jedynie o wynagrodzeniu, jakie można przyznać członkom rady nadzorczej. Z treści tego przepisu nie można wyprowadzić wniosku, w jaki sposób wynagrodzenie to ma być określone. Ustawodawca przekazał kompetencję do określenia wynagrodzenia członków rady nadzorczej walnemu zgromadzeniu, które podejmuje stosowną uchwałę lub reguluje kwestię wynagrodzenia w statucie spółki. Oznacza to, że walne zgromadzenie może określić wysokość wynagrodzenia członków rady nadzorczej w sposób dowolny, także poprzez wskazanie elementów fakultatywnych wynagrodzenia, których przyznanie zależeć będzie od tego, czy członkowie rady nadzorczej będą wykonywać dodatkowe obowiązki zlecone im przez radę". Powyższy pogląd należy odnieść odpowiednio do wynagrodzenia członków zarządu spółki akcyjnej.

3. Szeroka autonomia w zakresie kształtowania wynagrodzeń członków organów w spółce akcyjnej jest konsekwencją zasady wolności umów (art. $353^{1}$ k.c. w zw. z art. 2 k.s.h.). Jednakże nie ma ona charakteru absolutnego. ${ }^{13}$ Należy uznać, że jedną z podstawowych zasad, które powinny być przestrzegane w ramach kształtowania wynagrodzeń członków organów spółki akcyjnej jest zasada słuszności. Zasada ta znajduje swoje umocowanie zarówno w normach prawnych, które wyróżniają się swoją doniosłością oraz szczególną rolą jaką pełnią, ${ }^{14}$ jak i w założeniach, ideach systemu prawa prywatnego. ${ }^{15}$ Trafnie wskazuje się $\mathrm{w}$ piśmiennictwie, że ,idee sprawiedliwości wyrównawczej realizowanej przez mechanizmy prawa prywatnego nie mogą być osiągnięte wyłącznie poprzez precyzyjną i wyczerpu-

13 A. Szumański (A. Szumański, (w:) S. Sołysiński, A. Szajkowski, A. Szumański, J. Szwaja, Kodeks spółek handlowych..., op. cit., t. III, s. 673) wskazuje na wyjątki w tym zakresie wynikające z przepisów ustawy z dnia 26 czerwca 1974 r. Kodeks pracy (t. jedn. Dz.U. z 1998 r. Nr 21, poz. 94 ze zm.) oraz z przepisów ustawy o wynagradzaniu osób kierujących niektórymi podmiotami prawnymi (Dz.U. z 2013 r. poz. 254 ze zm.; tzw. ustawa kominowa).

14 Z. Radwański, Prawo cywilne - część ogólna, 2011 s. 197. Należy wskazać na toczącą się dyskusję odnośnie normatywnego lub pozanormatywnego statusu zasad prawa prywatnego; szerzej argumenty uczestników tej dyskusji przedstawia M. Safjan, Zasady prawa prywatnego, (w:) Z. Radwański (red. SPP), M. Safjan (red. tomu), Prawo cywilne - część ogólna. System Prawa Prywatnego, t. I, Warszawa 2012, s. 319 i n. i przywołana tam literatura. M. Safjan prezentuje stanowisko, że zasady prawa w istocie są normą wykreowaną w oparciu o rekonstrukcje podstawowych założeń, wartości i idei wynikających z całości danego systemu, gałęzi lub dziedziny prawa, M. Safjan, Zasady prawa prywatnego..., op. cit., s. 321.

15 A. Doliwa, Prawo cywilne - część ogólna, Warszawa 2004, s. 8; A. Wolter, J. Ignatowicz, K. Stefaniuk, Prawo cywilne. Zarys części ogólnej, Warszawa 2003 , s. 31. 
jącą regulację prawną, musi ona bowiem pozostawiać konieczny „luz decyzyjny” dla organów stosujących prawo, zapewniać elastyczność rozwiązań, które mogą być w najbardziej adekwatny sposób dostosowane do okoliczności konkretnych sytuacji prawnych" ${ }^{16}$ Podstawową funkcją zasady słuszności jest funkcja dyrektywna w procesie wykładni przepisów prawa oraz rekonstrukcji normy prawnej w przypadku luk normatywnych. ${ }^{17}$ Określając zakres przedmiotowy zasady słuszności należy zwrócić uwagę na jej szeroki stopień ogólności, który znajduje potwierdzenie i rozwinięcie w odpowiednio szerokiej palecie środków służących stosowaniu tej zasady. Mechanizmy umożliwiające stosowanie zasad słuszności w prawie prywatnym, $\mathrm{w}$ tym inkorporacji reguł pozasystemowych, są zróżnicowane. ${ }^{18} \mathrm{~W}$ prawie prywatnym podstawowym instrumentem wprowadzania reguł słusznościowych są przede wszystkim tzw. klauzule generalne, które odsyłają do ocen i kryteriów leżących poza systemem prawa. ${ }^{19}$ Podczas omawiania problematyki wynagrodzeń członków organów spółek akcyjnych, wśród klauzul odsyłających do wartości etyczno-moralnych, na plan pierwszy wysuwa się klauzula dobrych obyczajów. ${ }^{20} \mathrm{~W}$ przywołanych powyżej przepisach k.s.h. dotyczących wynagrodzeń organów spółki akcyjnej brak jest bezpośredniego odesłania do dobrych obyczajów. W przypadku spółki akcyjnej odwołanie do dobrych obyczajów wskazane jest w przepisach art. $304 \S 4$ i art. $422 \S 1$ k.s.h. ${ }^{21}$

16 M. Safjan, Zasady prawa prywatnego..., op. cit., s. 355.

17 S. Wronkowska, M. Zieliński, Z. Ziembiński, Zasady prawa, Warszawa 1974, s. 53.

18 M. Safjan wskazuje się, że można wyróżnić instrumenty bezpośrednio służące temu celowi, jak i te, które to pośrednio chronią określoną aksjologię systemu poprzez elastyczność stosowanych kryteriów wymagających uwzględnienia złożoności i zróżnicowania konkretnych stosunków prawnych (M. Safjan, Zasady prawa prywatnego..., op. cit., s. 356). Na realizację określonych założeń aksjologicznych systemu znacząco wpływa również orzecznictwo oraz poglądy doktryny.

19 Zob. M. Tarska, Zakres swobody umów w spółkach handlowych, Warszawa 2012, s. 134 i n.

20 Trafnie wskazuje W. Popiołek (W. Popiołek, (w:) K. Pietrzykowski (red.), Kodeks cywilny, Komentarz, t. I, Warszawa 2011, s.1434), że „dotychczasowa praktyka rozumienia tego pojęcia (tj. „dobre obyczaje” - dop. E.S.) kształtowała się na tle przepisów art. 16 ust. 1 pkt 1 ZNKU, art. $240 \S 2$ i art. $414 \S 1$ kh. (obecnie art. $249 \S 1$ i art. $422 \S 1 \mathrm{KSH}$ ). Na tej podstawie wskazać trzeba, że istotą dobrego obyczaju jest szeroko rozumiany szacunek dla drugiego człowieka”. M. Tarska (M. Tarska, Zakres swobody umów..., op. cit., s. 76) podkreśla, że poprzez dobre obyczaje należy rozumieć „wskazówki postępowania istniejące obiektywnie w poczuciu etycznym społeczeństwa, których identyfikacji i oceny dokonuje sędzia orzekający w danej sprawie”. Literatura dotycząca klauzuli dobrych obyczajów jest bardzo liczna, zob. m.in. L. Leszczyński, Tworzenie klauzul generalnych odsyłających, Lublin 2000; M. Poźniak-Niedzielska, Kilka uwag o zachowaniu dobrych obyczajów w działalności gospodarczej, (w:) Księga Pamiątkowa ku czci Profesora Wiesława Chrzanowskiego. lustitia Civitatis Fundamentum, Towarzystwo Naukowe KUL, Lublin 2003, s. 171 i n.; Z. Radwański, M. Zieliński, Normy i przepisy prawa cywilnego, (w:) Z. Radwański (red. SPP), M. Safjan (red. tomu), Prawo cywilne - część ogólna, System Prawa Prywatnego, t. I, Warszawa 2012, s. 398 i n.; Z. Radwański, M. Zieliński, Uwagi de lege ferenda o klauzulach generalnych w prawie prywatnym, PL 2001, nr 2, s. 11 i n.

21 Warto zauważyć, że w przepisach dotyczących statutu spółki akcyjnej oraz zaskarżania uchwał walnego zgromadzenia posłużono się trafnie pojęciem „dobre obyczaje”, a nie „zasady współżycia społecznego”. Szerzej nt. dyskusji odnośnie dobrych obyczajów a zasad współżycia społecznego zob. m.in. Ł. Gasiński Granice swobody kształtowania treści statutu spółki akcyjnej, Warszawa 2014, s. 222 i n.; M. Safjan, Klauzule generalne w prawie cywilnym (przyczynek do dyskusji), PiP 1990, nr 11; M. Tarska, Zakres swobody umów..., op. cit., s. 73 i n.; Z. Radwański, M. Zieliński, Uwagi de lege ferenda..., op. cit., s. 19 i n.; A. Tomaszek, Dobre obyczaje czy zasady współżycia społecznego, Rzeczp. 1997, nr 271, s. 17. Ustawodawca w przepisie art. 422 § 1 k.s.h. odszedł również od występującego w przepisach Kodeksu handlowego terminu „dobre obyczaje kupieckie” (por. art. 414 k.h.). 
$\mathrm{Na}$ klauzulę dobrych obyczajów przy określaniu wynagrodzenia członków organów spółki akcyjnej powołał się SA w Lublinie. W postanowieniu z dnia 26 czerwca 2012 r. ${ }^{22}$ SA w Lublinie słusznie orzekł, że nie można uznać za zgodne z dobrymi obyczajami uchwał, które ustalają wynagrodzenie dla przewodniczącego rady nadzorczej, jego zastępcy i sekretarza w wysokości wyższej od wynagrodzenia ,niefunkcyjnego" członka rady nadzorczej o odpowiednio 25, 15 i 10 razy. W uzasadnieniu tego postanowienia sąd podkreślił, że za pozostającą w sprzeczności z dobrymi obyczajami należy uznać uchwałę sprzeczną z normami moralnymi i obyczajowymi oraz godzącą w poczucie przyzwoitości. Zakres czynności wykonywanych przez przewodniczącego rady nadzorczej, jego zastępcy i sekretarza w porównaniu do ,niefunkcyjnych” członków rady nadzorczej nie usprawiedliwia tak istotnych różnic w wynagrodzeniu, w szczególności w odniesieniu do członków rady nadzorczej, którzy zostali wybrani do stałego indywidualnego wykonywania czynności nadzorczych. ${ }^{23}$ Ponadto SA w Lublinie trafnie podkreślił, że różnice w sposobie wynagradzania w zależności od podmiotu, który uczestniczył w wyborze danego członka rady nadzorczej, ${ }^{24}$ są sprzeczne z dobrymi obyczajami, jak też mogą negatywnie oddziaływać na funkcjonowanie spółki, tj. powodować konflikty wewnątrz organu, a w konsekwencji uniemożliwiać jego prawidłowe funkcjonowanie. Takie uchwały pozostają - zdaniem SA w Lublinie - w sprzeczności z normami obyczajowymi i godzą w poczucie przyzwoitości.

4. Należy dostrzec rozbieżności w doktrynie odnośnie kryteriów ocennych, jakie należy stosować odwołując się do dobrych obyczajów. ${ }^{25}$ Przy określaniu pojęcia „dobre obyczaje” w doktrynie prawa prywatnego widoczne są odwołania do moralności, ${ }^{26}$ ale również prawego społeczeństwa ${ }^{27}$ czy wartości chrześcijańskich. ${ }^{28}$ W przepisach k.s.h. nie sprecyzowano, jak należy rozumieć pojęcie „dobre obyczaje", dlatego należy dokonać analizy orzecznictwa oraz poglądów przedstawicieli piśmiennictwa w tym zakresie. Na gruncie prawa handlowego można wyodrębnić trzy stanowiska odnośnie zakresu tego pojęcia. Zgodnie z pierwszym poglądem termin „dobre obyczaje” może być rozumiany bardzo szeroko poprzez odwołanie się

22 Synatura: I ACz 609/12, niepublikowane.

23 W opinii tego sądu, w ten sam sposób należy ocenić symboliczne wynagrodzenie przyznane członkom rady nadzorczej, którzy zostali wybrani do stałego indywidualnego wykonywania czynności nadzorczych.

24 W stanie faktycznym tej sprawy wskazane w uchwałach wynagrodzenie członków rady nadzorczej wybranych przez akcjonariuszy mniejszościowych pozostaje w rażącej dysproporcji do wynagrodzenia przyznanego tym członkom, którzy zostali wybrani przez akcjonariusza większościowego.

25 Należy zauważyć, że klauzula generalna dobrych obyczajów odnoszona do wynagrodzenia członków organów spółek kapitałowych nie odnosi się do wszystkich dobrych obyczajów, ale tych, które mają „użyteczny zakres”. Interpretując klauzulę dobrych obyczajów w odniesieniu do określenia wynagrodzenia członków organów spółki akcyjnej należy odwołać się do przepisów art. 304 § 4 i art. 422 § 1 k.s.h., w których odwołano się do tego pojęcia. Por. A. Żurawik, Klauzula generalna „dobrych obyczajów” - ujecie teoretyczne, RPEiS 2009, z. 1, s. 50.

26 Szeroko przegląd poszczególnych kryteriów ocennych przedstawia A. Żurawik, Klauzula generalna „dobrych obyczajów"..., op. cit., s. 37 i n. oraz przywołana tam literatura.

27 A. Szpunar, Nadużycie prawa podmiotowego, Kraków 1947, s. 65 i n.

28 A. Żurawik, Klauzula generalna „dobrych obyczajów”..., op. cit., s. 46 i n. 
do norm moralnych i obyczajowych godzących w poczucie przyzwoitości, interpretowane w odniesieniu do przeciętnego poziomu moralnego, w kontekście szacunku dla drugiego człowieka. W wyroku z dnia 20 czerwca 2001 r., I CKN 1137/9829 - odnoszącym się jeszcze do art. $240 \S 2$ k.h. i użytego w tym przepisie pojęcia „dobry obyczaj kupiecki” - SN wskazał, że ta przesłanka „ma wyraźnie aspekt moralny i może być rozpatrywana tylko w kategoriach niegodziwości zachowań oraz naganności zamierzonych celów, ze szkodą dla interesów spółki”. Za takim ujęciem tego terminu opowiada się S. Sołtysiński ${ }^{30}$ podnosząc, że w przepisach k.s.h. nie zawężono pojęcia „,dobre obyczaje” jedynie do norm uczciwego postępowania obowiązujących wśród przedsiębiorców, ale również do norm moralnych panujących w społeczeństwie.

$\mathrm{Na}$ podstawie drugiego stanowiska określając zakres terminu „dobre obyczaje" należy posługiwać się kryteriami ekonomiczno-funkcjonalnymi i ocenami zorientowanymi na zapewnienie niezakłóconego funkcjonowania i rozwoju spółki kapitałowej. W wyroku z dnia 8 marca 2005 r., IV CK 607/04 ${ }^{31}$ SN stwierdzil, że „sprzeczność uchwały z dobrymi obyczajami występuje wówczas, gdy w obrocie handlowym może być ona uznana za nieetyczną. Chodzi przy tym jednak raczej nie o ocenę z punktu widzenia etyki przeciętnego, uczciwego człowieka, lecz o oceny nastawione na zapewnienie niezakłóconego funkcjonowania spółki pod względem ekonomicznym". Warto zwrócić uwagę również na stanowisko SA we Wrocławiu przedstawione w wyroku z dnia 16 stycznia 2007 r. ${ }^{32}$ zgodnie z którym ,uchwała walnego zgromadzenia akcjonariuszy pozwanej spółki (...) podjęta została z naruszeniem dobrych obyczajów rozumianych jako zespół norm moralnych i zwyczajowych wpływających na funkcjonowanie spółki oraz jej otoczenie „gospodarcze” i związanych z przestrzeganiem uczciwości „kupieckiej” przy prowadzeniu działalności gospodarczej. Podkreślić przy tym należy, że obecnie to pojęcie definiowane jest przez pryzmat kryterium ekonomiczno-funkcjonalnego, odwołującego się do oceny zorientowanej na zapewnienie niezakłóconego funkcjonowania gospodarki, a nie do poglądów uczciwego, przeciętnego człowieka”. Prezentując ten pogląd SA we Wrocławiu powołał się na stanowisko przedstawione przez J. Szwaję. W opinii J. Szwai należy stosować ,podejście, które można nazwać ekonomiczno-funkcjonalnym. Kryterium powinny więc stanowić nie poglądy uczciwego, przeciętnego człowieka, i nie tylko oceny moralne, ale oceny zorientowane na zapewnienie niezakłóconego funkcjonowania gospodarki". ${ }^{33}$

Zgodnie z trzecim stanowiskiem określając zakres pojęcia „,dobre obyczaje” należy odnieść się do norm moralnych, jednakże uwzględniając specyfikę spółki han-

OSNC $2002 \mathrm{nr}$ 3, poz. 31, s. 5.

S. Sołtysiński, Nieważne i wzruszalne uchwały zgromadzeń spółek kapitałowych, PPH 2006, nr 1, s. 14. LEX nr 289387.

I ACa 1461/06, OSG 2007 nr 8, poz. 92, s. 48, OSA/Wr 2007, nr 2, poz. 26, OSAW 2007/2/26.

J. Szwaja, (w:) S. Sołtysiński, A. Szajkowski, A. Szumański, J. Szwaja, Kodeks spółek handlowych..., op. cit., t. III, s. 1369 . 
dlowej. Warto zwrócić uwagę na stanowisko SN przedstawione w wyroku z dnia 27 marca 2013 r., I CSK 407/12. ${ }^{34} \mathrm{~W}$ uzasadnieniu do tego wyroku SN wskazał, że „dobre obyczaje”, w rozumieniu art. $422 \S 1$ k.s.h., postrzegane są jako ogólne reguły uczciwości kupieckiej obowiązujące wszystkich uczestników obrotu gospodarczego przy prowadzeniu działalności gospodarczej, w tym spółki akcyjne (przedsiębiorców), jej organy statutowe i samych akcjonariuszy. ${ }^{35} \mathrm{~W}$ opinii A. Szajkowskiego i M. Tarskiej dobre obyczaje ,należy ujmować w nieco innym aspekcie niż w przypadku ZNKU, tzn. w znaczeniu bliższym sensowi w jakim ustawodawca używa klauzul słusznościowych w przepisach kc. - to jednak należy to czynić przy uwzględnieniu właściwości stosunku prawnego spółki handlowej, w tym kształtujących jej naturę prawną elementów konstrukcyjnych charakterystycznych dla spółki jako formy współdziałania opartej przede wszystkim na kapitale". ${ }^{36}$

Z powyższej analizy wynika, że termin ,dobre obyczaje" w doktrynie i orzecznictwie dotyczącym prawa handlowego może być różnorodnie interpretowany. Jednakże określając zakres tego pojęcia należy wskazać, że powinno się mieć na uwadze z jednej strony utrwalone reguły uczciwości kupieckiej nastawione na niezakłócone funkcjonowanie spółki oraz poszanowanie interesów jej, a także akcjonariuszy, a $\mathrm{z}$ drugiej strony zasady etyczne dotyczące przyzwoitego $0^{37}$ zachowania obowiązujące pomiędzy wspólnikami lub akcjonariuszami. Wartości te wzajemnie się uzupełniają. Należy podzielić stanowisko SA w Szczecinie przedstawione w wyroku z dnia 26 kwietnia 2013 r., ${ }^{38} \mathrm{~W}$ którym uznał, że ,przesłanka braku zgodności uchwały z dobrymi obyczajami nakazuje weryfikację uchwały według etyczno-moralnych kryteriów oceny postępowania w działalności gospodarczej. Pojęcie «dobre obyczaje» odnosi się nie tylko do uczciwości kupieckiej skierowanej na zewnątrz spółki (w stosunku do innych uczestników obrotu gospodarczego), ale również do stosunków wewnętrznych w spółce, w tym relacji pomiędzy wspólnikami." Wobec powyższego wątpliwe wydaje się być ograniczenie zakresu terminu ,dobre obyczaje” wyłącznie do „obyczajów kupieckich” nastawionych na dobre niezakłócone funkcjonowanie spółki.

W wyroku Sądu Apelacyjnego w Warszawie z dnia 8 lutego 2013 r. ${ }^{39}$ trafnie podkreślono, że ,dobre obyczaje powstają na przestrzeni określonego (zazwyczaj dłuższego) czasu tak, że przez ich powtarzalność stają się «dobre» (aprobowane,

\footnotetext{
34 OSP 2013/11/108.

35 W wyroku z dnia 8 lutego 2013 r. Sąd Apelacyjny w Warszawie definiując „dobre obyczaje” wskazał, że „chodzi więc o przyzwoite postępowanie, które uwzględnia w odpowiednim stopniu różne interesy służące wszystkim w spółce".

36 A. Szajkowski, M. Tarska, (w:) S. Sołtysiński, A. Szajkowski, A. Szumański, J. Szwaja, Kodeks spółek handlowych. Komentarz, t. II, Warszawa 2014, s. 696.

37 Zgodnie z definicją podaną w słowniku języka polskiego „przyzwoity” to: „1. postępujący zgodnie z normami moralnymi i obyczajami; też: świadczący o takim postępowaniu; 2. taki jak należy.” http://sjp.pwn.pl/slownik/2512925/ przyzwoity.

38 I ACa 749/12, LEX nr 1378860

39 VIACa 1124/12, LEX nr 1344285.
} 
przyjęte, w końcu wymagane), co należy odnosić jako kierunek zmian stosunków w obrocie. Jeżeli w grupie spółek określonej branży przyjęte są pewne «normy» wewnętrzne, czasem mające wymiar etyczny, należy ich przestrzegać. Zdarzyć się może, że będą one miały formę spisaną (...)". Dobre obyczaje powinny być zachowywane przez spółki, które działają w ramach różnego rodzaju zrzeszeń (organizacji). W przywoływanym już wyroku z dnia 16 stycznia 2007 r. (I ACa 1461/06) SA we Wrocławiu wskazał, że dobre obyczaje mogą być rozumiane również jako dobre praktyki, które „zostały niejako skodyfikowane i ujęte w pisemną formę «Zasad Ładu Korporacyjnego». Właśnie w przypadku spółek akcyjnych szczególne znacznie mają zasady ładu korporacyjnego skierowane do publicznych spółek akcyjnych. Dobre Praktyki Spółek Notowanych na GPW ${ }^{40}$ należą do kategorii tzw. soft law, co oznacza, że postanowieniom w nim zawartym nie można przypisać mocy powszechnie obowiązującego prawa. Zgodnie z Preambułą Dobre Praktyki objęte częściami II, III i IV opierają się na regule «comply or explain» (przestrzegaj lub wyjaśnij). Oznacza ona, że spółki, które dokonają odstępstwa od Dobrych Praktyk zawartych w tych częściach mają obowiązek wyjaśnić w oświadczeniu które z zasad ładu korporacyjnego nie będą stosowały i jakie są tego powody." ${ }^{41}$ Zatem chociaż podporządkowanie się im jest fakultatywne, to obowiązkowe jest poinformowanie przez spółkę, objętą zakresem podmiotowym Dobrych Praktyk, o odstępstwie od stosowania poszczególnych postanowień tych zasad ładu korporacyjnego. ${ }^{42}$ Jednakże Dobre Praktyki określone w części I, zgodnie z Preambułą, ,są zaleceniami, które nie podlegają w pełni takiemu mechanizmowi (tzn. regule przestrzegaj lub wyjaśnij - dop. E.S.), ale wyrażają tendencje w zakresie właściwego sposobu układania relacji wewnętrznych i relacji spółek giełdowych z ich otoczeniem i z tego względu podobnie jak zasady objęte częściami II, III i IV są przedmiotem corocznych sprawozdań dotyczących postępowania w zakresie przestrzegania zasad ładu korporacyjnego, sporządzanych przez spółki giełdowe" ${ }^{43}$ Taki sposób sformułowania skutków prawnych stosowania bądź nie zasad objętych częścią I Dobrych Praktyk „Rekomendacje dotyczące dobrych praktyk spółek giełdowych”, zwłaszcza ze względu na jej zakres przedmiotowy, może budzić pewne wątpliwości.

Stanowią one załącznik do uchwały nr 19/1307/2012 Rady Giełdy z dnia 21 listopada 2012 r. i obowiązują w obecnej wersji od dnia 1 stycznia 2013 r.; dalej jako: Dobre Praktyki.

41 Por. motyw szósty zalecenia Komisji z dnia 9 kwietnia 2014 r. w sprawie jakości sprawozdawczości dotyczącej ładu korporacyjnego (podejście „przestrzegaj lub wyjaśnij”) (2014/208/UE); Dz. Urz. L 109, poz. 43.

42 Por. $\S 29$ ust. 2 zdanie 2 Regulaminu Giełdy oraz $\S 91$ ust. 5 pkt 4 Rozporządzenie Ministra Finansów z dnia 19 lutego 2009 roku w sprawie informacji bieżących i okresowych przekazywanych przez emitentów papierów wartościowych oraz warunków uznawania za równoważne informacji wymaganych przepisami prawa państwa niebędącego państwem członkowskim (Dz.U. z dnia 28 lutego 2009 r.). Ponadto, art. 20 ust. 1 dyrektywy Parlamentu Europejskiego i Rady 2013/34/UE z dnia 26 czerwca 2013 r. w sprawie rocznych sprawozdań finansowych, skonsolidowanych sprawozdań finansowych i powiązanych sprawozdań niektórych rodzajów jednostek, zmieniająca dyrektywę Parlamentu Europejskiego i Rady 2006/43/WE oraz uchylająca dyrektywy Rady 78/660/ EWG i 83/349/EWG (Dz. Urz. L 182, poz. 19) zobowiązuje spółki notowane na rynku regulowanym do przedstawiania wyjaśnień w przypadku odstępstwa od zaleceń kodeksu ładu korporacyjnego, któremu te spółki podlegają lub który zdecydowały dobrowolnie stosować. 
Obecnie obowiązujące Dobre Praktyki jedynie ogólnie regulują kwestie wynagrodzeń członków organów spółki. Zgodnie z pkt I. 5. Dobrych Praktyk „spółka powinna posiadać politykę wynagrodzeń oraz zasady jej ustalania. Polityka wynagrodzeń powinna w szczególności określać formę, strukturę i poziom wynagrodzeń członków organów nadzorujących i zarządzających”. Przy czym Dobre Praktyki nie precyzują zasad polityki wynagrodzeń, ale jedynie odsyłają w tym zakresie do unijnych zaleceń. ${ }^{44} \mathrm{Na}$ podstawie pkt I. 5. zdanie 3 Dobrych Praktyk ,,przy określaniu polityki wynagrodzeń członków organów nadzorujących i zarządzających spółki powinno mieć zastosowanie zalecenie Komisji Europejskiej z dnia 14 grudnia 2004 r. w sprawie wspierania odpowiedniego systemu wynagrodzeń dyrektorów spółek notowanych na giełdzie (2004/913/WE), uzupełnione o zalecenie Komisji Europejskiej z dnia 30 czerwca 2009 r. (2009/385/WE) ${ }^{45}$ ". Zatem spółki objęte zakresem Dobrych Praktyk powinny stosować zalecenia Komisji, które dotyczą wynagrodzeń członków organów spółek akcyjnych i obejmują cztery obszary. Pierwszy z nich obejmuje strukturę polityki wynagrodzeń. ${ }^{46}$ Odpowiednia polityka wynagrodzeń powinna zapewnić stosowanie zasady płaca za wyniki i zachęcać „dyrektorów”47 do zapewniania średnio- i długoterminowej stabilności prowadzonych przez nich

44 Zalecenie jest, zgodnie z art. 288 akapit 5 TFUE, unijnym aktem prawnym, który „nie ma mocy wiążącej”. Brak mocy prawnie wiążącej oznacza, że zalecenia nie mogą przyznawać jednostkom uprawnień i nie mogą nakładać nań obowiązków. Ponadto, państwa członkowskie nie są zobowiązane do ich implementacji, a brak implementacji nie rodzi uprawnienia do żądania odpowiedzialności odszkodowawczej państwa członkowskiego za naruszenie praw unijnego. Jednakże w wyroku w sprawie Grimaldi (z 13.12.1989 r. w sprawie C-322/88, Rec. s. 4407, pkt 8 i 18) TS uznał, że zaleceniom nie można odmówić pewnych konsekwencji prawnych, a zatem sędziowie sądów krajowych powinni „uwzględniać je” przy rozstrzyganiu rozpatrywanych przez siebie sporów. Dotyczy to w szczególności sytuacji, gdy sędziowie dokonują wykładni norm prawa krajowego przyjętych celem ich rozwinięcia lub gdy uzupełniają unijne przepisy posiadające moc obowiązującą. W piśmiennictwie trafnie wskazuje się, że w przypadku, gdy państwo członkowskie dobrowolnie implementuje przepisy zalecenia, wówczas organy i sądy tego państwa członkowskiego „mogą być obowiązane do wzięcia pod rozwagę zalecenia przy dokonywaniu wykładni praw krajowego implementującego to zalecenie" (A. Wróbel, Komentarz do art. 288, (w:) A. Wróbel (red.), Traktat o funkcjonowaniu Unii Europejskiej. Komentarz, Warszawa 2012, t. II, s. 692).

45 Zalecenie Komisji Europejskiej z dnia 30 kwietnia 2009 r. uzupełniające zalecenia 2004/913/WE i 2005/162/ WE w sprawie systemu wynagrodzeń dyrektorów spółek notowanych na rynku regulowanym (2009/385/WE). Warto zauważyć, że wobec problemu stosowania ryzykownych praktyk w zakresie usług finansowych Komisja uznała za słuszne ustanowienie odrębnych zasad mających zastosowanie do polityki wynagrodzeń w tym sektorze w celu zminimalizowania ryzyka, które przyczynia się do osłabienia systemu finansowego jako całości. Zob. zalecenie Komisji z dnia 30 kwietnia 2009 r. w sprawie polityki wynagrodzeń w sektorze usług finansowych, Dz.U. L 120 z 15.5.2009 r., s. 22 i n. Por. również Sprawozdanie Komisji dla Parlamentu Europejskiego, Rady, Europejskiego Komitetu Ekonomiczno-Społecznego oraz Komitetu Regionów. Sprawozdanie w sprawie zastosowania przez państwa członkowskie UE zalecenia Komisji 2009/384/WE w sprawie polityki wynagrodzeń w sektorze usług finansowych (zalecenia z 2009 r. w sprawie polityki wynagrodzeń w sektorze usług finansowych) (KOM(2010) 286 wersja ostateczna).

46 W opinii Komisji struktury wynagrodzeń członków organów spółek akcyjnych ulegały coraz dalej idącej komplikacji i nadmiernemu powiązaniu z wynikami krótkoterminowymi, w niektórych przypadkach prowadząc do zbyt wysokich wynagrodzeń, nie znajdujących uzasadnienia w wynikach pracy wynagradzanych osób. Por. motyw 2 zalecenia 2009/385.

$47 \quad$ Na marginesie warto zauważyć, że w zaleceniach Komisji dotyczących wynagrodzeń w polskiej wersji językowej posłużono się terminem „dyrektor" [direktor (ang.), Mitglied der Unternehmensleitung (niem.), administratur (fr.), amministratore (wł.), členem správního orgánu (czes.)] na określenie „członka organu administracji, zarządu lub nadzoru spółki notowanej na giełdzie" (pkt. 2.1 zalecenia 2004/913). Należy krytycznie ocenić taką wersję językową tego terminu, przede wszystkim ze względu na to, że pojęcie „dyrektor” ma zwyczajowo odmienny zakres pojęciowy i może wprowadzać w błąd. Wydaje się, że bardziej adekwatne byłoby użycie terminu „członek organu"; por. M. Spyra, Spółka akcyjna, (w:) Prawo spółek handlowych. System Prawa Handlowego, t. II , Warszawa 2012, s. 1181. 
spółek. Zalecenia Komisji, w zakresie projektowania odpowiedniej polityki wynagrodzeń, opierają się na konieczności ustalenia odpowiednich proporcji pomiędzy stałymi a zmiennymi składnikami wynagrodzenia. Przy czym zaleca się powiązanie zmiennych składników z kryteriami wynikowymi, które powinny sprzyjać długoterminowej stabilności przedsiębiorstwa, ${ }^{48} \mathrm{np}$. poprzez ustalenie limitu zmiennych składników wynagrodzenia.

Z pkt 3.3 zalecenia 2009/385 wynika, że w przypadku przyznania prawa do zmiennego składnika wynagrodzenia, jego większa część powinna być odraczana na określony minimalny okres nabywania uprawnień. Odroczenie zmiennych składników wynagrodzenia oznacza, że są one przyznawane na podstawie wieloletnich kryteriów wynikowych lub ich ostateczne przyznanie jest odkładane przez kilka lat, do czasu spełnienia określonych kryteriów wynikowych. ${ }^{49} \mathrm{~W}$ pkt. 3.4. zalecenia 2009/385 podkreśla się, że uzgodnienia zawarte w umowie w przypadku dyrektorów wykonawczych lub zarządzających powinny uwzględniać postanowienia umożliwiające spółce żądanie zwrotu zmiennych składników wynagrodzenia wypłaconych na podstawie danych, które okazały się w oczywisty sposób nieprawdziwe.

Jednym z kontrowersyjnych problemów, do których odniosła się Komisja, były odprawy z tytułu rozwiązania umowy (tzw. ,złote spadochrony”).$^{50}$ Wobec praktyki wypłacania bardzo wysokich odpraw, niezależnie od wyniku finansowego spółki, celem unijnych wytycznych jest zagwarantowanie, aby odprawy nie stanowily nagrody za niepowodzenie gospodarcze, ale by faktycznie pełniły podstawową funkcję zabezpieczenia w sytuacji wcześniejszego ustania stosunku umownego. ${ }^{51}$ Dlatego zdaniem Komisji wypłaty odpraw z tytułu rozwiązania umowy należy ograniczyć do określonej kwoty i okresu wypowiedzenia. Jak wynika z pkt 3.5 zalecenia 2009/385 odprawy nie powinny przekraczać określonej kwoty lub liczby lat wynagrodzenia stałego ${ }^{52}$ i nie powinny być wypłacane z tytułu rozwiązania umowy ze względu na niezadowalające wyniki lub na wniosek pracownika. Stosując te unijne rekomendacje w niektórych państwach członkowskich wprowadzono ograniczenia odpraw do wysokości jednorocznego wynagrodzenia stałego. ${ }^{53}$

Drugi obszar zagadnień uregulowanych $\mathrm{w}$ analizowanych unijnych zaleceniach, w zakresie wynagrodzeń członków organów spółek akcyjnych, obejmuje kwestię wynagrodzenia opartego na akcjach. ${ }^{54} \mathrm{~W}$ pkt. 4.1 zalecenia 2009/385 podkreślono, że

$48 \quad$ Pkt 3.2 zalecenia 2009/385.

49 Por. Sprawozdanie, przypis 13.

50 Bardzo wysokie świadczenia z tytułu odprawy członków zarządów spółek były przedmiotem wielu informacji prasowych, zob. np. J. Krawędkowski, Prezesi ze „złotym spadochronem”, czyli milionowe odprawy w polskich firmach, „Gazeta Prawna” z dnia 12 lipca 2013 r.

51 Por. motyw 7 zalecenia 2009/385.

52 W pkt 3.5 zalecenia 2009/385 rekomenduje się, aby kwota odprawy nie przekraczała dwuletniego wynagrodzenia stałego (wliczając wyłącznie stałą składową wynagrodzenia w skali roku).

53 M.in. w Niderlandach i Wielkiej Brytanii; por. przypis 16 Sprawozdania.

54 Odnośnie dyskusji dotyczącej celowości uwzględnienia i sposobu uregulowania zob. szerzej M. Cejmer, Zalecenia Komisji w sprawie wynagrodzeń dyrektorów spółek notowanych na rynku regulowanym, (w:) M. Cejmer, J. Napierała, T. Sójka. (red.), Europejskie Prawo Spółek, t. III. Corporate Governance, Kraków 2006, s. 437 i n. 
prawa własności akcji nie powinny nabierać mocy wcześniej niż po upływie co najmniej trzech lat od czasu ich przyznania w formie wynagrodzenia. Prawo egzekwowania opcji na akcje lub innych uprawnień do nabycia akcji bądź do wynagrodzenia na podstawie zmian cen akcji powinno być zastrzeżone przez okres przynajmniej trzech lat od chwili ich przyznania. Komisja zaleciła również, aby nabywanie praw własności akcji i prawa do egzekwowania opcji na akcje były powiązane z określonymi z góry, wymiernymi kryteriami wynikowymi. Ponadto, ograniczono zakres podmiotowy tej formy wynagrodzenia. Z pkt 4.4. zalecenia 2009/385 wyraźnie wynika, że akcje nie powinny stanowić formy wynagrodzenia w systemie dualistycznym dyrektorów będących członkami organu nadzorczego. ${ }^{55}$

Trzeci obszar dotyczący wynagrodzeń członków organów spółek akcyjnych obejmuje zagadnienie jawności polityki wynagrodzeń. Zgodnie z pkt. 3.1 zalecenia 2004/913 każda spółka notowana na giełdzie powinna przedstawić deklarację ujawniającą politykę wynagrodzeń spółki (,deklaracja dotycząca wynagrodzeń”). ${ }^{56}$ Do jej elementów obligatoryjnych należy:

- wyjaśnienie względnego znaczenia zmiennych i stałych elementów wynagrodzenia dyrektorów (pkt 3.1 a) zalecenia 2004/913);

- wystarczająca informacja na temat kryteriów wydajności, stanowiących podstawę uprawnień do opcji na akcje, akcji lub zmiennych elementów wynagrodzenia (pkt 3.1 b) zalecenia 2004/913);

- wystarczające informacje na temat związku między wydajnością a wynagrodzeniem;

- główne parametry oraz uzasadnienie systemu premii rocznych i wszelkich innych świadczeń niepieniężnych (pkt 3.1 c) zalecenia 2004/913);

- opis głównych cech charakterystycznych dodatkowych programów emerytalno-rentowych lub programów wcześniejszych emerytur dla dyrektorów (pkt 3.1 d) zalecenia 2004/913);

- objaśnienie sposobu, w jaki wybór kryteriów wynikowych przyczynia się do długofalowych interesów przedsiębiorstwa zgodnie z pkt 3.2 zalecenia 2009/385 (pkt 5.2 a) zalecenia 2009/385);

- objaśnienie metod stosowanych do rozstrzygnięcia, czy spełnione zostały kryteria wynikowe (pkt 5.2 b) zalecenia 2009/385);

- wystarczające informacje na temat okresu odroczenia w odniesieniu do zmiennych składników wynagrodzenia, o których mowa w pkt 3.3 zalecenia 2009/385 (pkt 5.2 c) zalecenia 2009/385); polityki wynagrodzeń przedsiębiorstwa i dla pogłębienia odpowiedzialności spółki wobec akcjonariuszy, deklaracja dotycząca wynagrodzeń była możliwie jasno i przystępnie sformułowana. Deklaracja dotycząca wynagrodzeń powinna stanowić część odrębnego raportu w sprawie wynagrodzeń oraz/lub jest ujęta w rocznych sprawozdaniach finansowych bądź w notach do rocznych sprawozdań finansowych spółki. Deklarację dotyczącą wynagrodzeń należy również zamieścić na stronie internetowej spółki. 
- wystarczające informacje dotyczące polityki w odniesieniu do odprawy z tytułu rozwiązania umowy, o której mowa w pkt 3.4 niniejszego zalecenia (pkt 5.2 d) zalecenia 2009/385);

- wystarczające informacje na temat okresu odroczenia w odniesieniu do wynagrodzenia opartego na akcjach, o którym mowa w pkt 4.1 zalecenia 2009/385 (pkt 5.2 e) zalecenia 2009/385);

- wystarczające informacje dotyczące polityki w odniesieniu do zachowania akcji po ich nabyciu, o którym mowa w pkt 4.3 zalecenia 2009/385 (pkt 5.2 f) zalecenia 2009/385);

- wystarczające informacje dotyczące składu grup analogicznych przedsiębiorstw, których polityka w sferze wynagrodzeń podlegała zbadaniu w trakcie określania polityki wynagrodzeń danego przedsiębiorstwa (pkt $5.2 \mathrm{~g}$ ) zalecenia 2009/385).

Jednakże tak szeroko zakreślony zakres deklaracji dotyczącej wynagrodzeń może powodować wątpliwości odnośnie ujawniania tych informacji nie tylko akcjonariuszom, ale również konkurencyjnym spółkom, a także może osłabiać szybkość reakcji spółki na zmiany rynkowe $\mathrm{w}$ tym zakresie. ${ }^{57}$ Unijny prawodawca zauważa takie niebezpieczeństwo umożliwiając na podstawie pkt. 3.3. zdanie 2 zalecenia 2004/913 nieujawnianie w deklaracji dotyczącej wynagrodzeń tych informacji handlowych, które mają znaczenie strategiczne dla spółki.

Czwarty obszar zagadnień uregulowanych przez Komisję w zakresie wynagrodzeń członków organów, do których powinny stosować się spółki akcyjne objęte zakresem podmiotowym Dobrych Praktyk, dotyczy kwestii zaangażowania i wpływu akcjonariuszy na wynagrodzenie członków organów. ${ }^{58} \mathrm{Komisja} \mathrm{zaleca,} \mathrm{aby} \mathrm{zachęcać}$ akcjonariuszy do uczestnictwa w walnych zgromadzeniach i rozważnego głosowania $\mathrm{w}$ tej materii. ${ }^{59} \mathrm{Zwłaszcza}$ akcjonariusze instytucjonalni powinni wykazać inicjatywę w kontekście gwarantowania pogłębionej odpowiedzialności rad nadzorczych W sferze wynagrodzeń. ${ }^{60} \mathrm{~W}$ pkt. 4.1 . zalecenia 2004/913 podkreślono, że polityka wynagrodzeń oraz wszelkie jej znaczące zmiany powinny stanowić odrębny punkt w planie corocznego walnego zgromadzenia, a deklarację dotyczącą wynagrodzeń należy poddać pod głosowanie corocznego walnego zgromadzenia akcjonariuszy.

57 Szerzej: M. Cejmer, Zalecenia Komisji w sprawie wynagrodzeń dyrektorów..., op. cit., s. 454 i n.

58 Zob. G. Ferrarini, N. Moloney, M.C. Ungureanu, Executive Remuneration in Crisis..., op. cit., s. 28 i n.

59 Należy wskazać na propozycję Komisji Europejskiej przedstawioną dnia 9 kwietnia 2014 r. dotyczącą zwiększenia zaangażowania akcjonariuszy i wprowadzenia zasady say on pay w około 10000 największych spółek notowanych na europejskich giełdach (IP/14/320). Komisarz ds. rynku wewnętrznego i usług M. Barnier powiedział m.in.: „Ostatnie lata po raz kolejny pokazały, jak krótkoterminowe myślenie szkodzi europejskim spółkom i gospodarce. Zdrowy ład korporacyjny może przyczynić się do zmiany tych tendencji. Dzisiejsze wnioski będą motywować akcjonariuszy do większego zaangażowania w spółki, w które inwestują, i do przyjęcia wobec swoich inwestycji perspektywy długoterminowej. W tym celu muszą oni mieć prawo do sprawowania właściwej kontroli nad kadrą zarządzającą, co obejmowałoby wiążącą zasadę say on pay (zakładającą, że wynagrodzenia menedżerów powinny być poddawane pod głosowanie akcjonariuszy)." 
Jednakże zalecenie nie przesądza, czy stanowisko akcjonariuszy ma mieć charakter wiążący czy doradczy. ${ }^{61}$ Niemniej jednak państwa członkowskie mogą postanowić, że takie głosowanie zostanie zorganizowane wyłącznie na wniosek akcjonariuszy reprezentujących co najmniej 25\% ogólnej liczby głosów akcjonariuszy obecnych lub reprezentowanych na walnym zgromadzeniu. Zgodnie z pkt. 4.2 ak. 2 zalecenia 2004/913 to postanowienie nie wyklucza prawa akcjonariuszy do przedłożenia uchwały zgodnie z przepisami krajowymi. Jednakże sam fakt, że akcjonariusze mają prawo głosu w sprawie polityki wynagrodzeń nie oznacza, w opinii Komisji, wspierania głosowania akcjonariuszy w sprawie polityki wynagrodzeń. ${ }^{62}$

Z powyższej prezentacji unijnych zaleceń dotyczących wynagrodzeń członków organów spółek akcyjnych może wynikać szereg trudności, w ich stosowaniu, dla spółek notowanych na GPW. Przede wszystkim unijne zalecenia adresowane są zarówno do członków organu monistycznego, jak i organów w systemie dualistycznym, co nakłada na polskie spółki akcyjne, w których przeważa obligatoryjny zarząd i rada nadzorcza, ${ }^{63}$ konieczność samodzielnej interpretacji i ,,adaptacji” niektórych rozwiązań prawnych do tych organów. Ponadto, szczegółowe uregulowanie polityki wynagrodzeń wobec braku precyzyjnego określenia takiego obowiązku w rekomendacjach Dobrych Praktyk ${ }^{64}$ budzi poważne wątpliwości co do realnego stworzenia przez spółki publiczne mechanizmów polityki wynagrodzeń. Co więcej, niektóre rozwiązania prawne przewidziane $\mathrm{w}$ analizowanych zaleceniach powodują wątpliwości, co do ich zgodności z przepisami k.s.h. ${ }^{65}$

Do kwestii wynagrodzeń odnosi się pośrednio pkt III. 6 ,Dobre Praktyki stosowane przez członków rad nadzorczych”, w którym określono, że co najmniej dwóch członków rady nadzorczej ,,powinno spełniać kryteria niezależności od spółki i podmiotów pozostających w istotnym powiązaniu ze spółką". W Dobrych Praktykach nie doprecyzowano pojęcia ,niezależność”, dlatego w tym zakresie należy stosować wytyczne zawarte w zaleceniu 2005/162. W pkt. 13.1 zalecenia 2005/162 określono, że ,dyrektora należy uznać za niezależnego, tylko kiedy nie ma powiązań gospodarczych, rodzinnych lub innych ze spółką, z jej akcjonariuszem mającym pakiet kontrolny lub kierownictwem, które skutkują sprzecznością interesów mogącą wpłynąć

$61 \quad$ Pkt 4.2 ak. 1 zalecenia 2004/913.

62 Por. Sprawozdanie.

63 Jedynie w polskiej spółce akcyjnej założonej jako europejska spółka akcyjna akcjonariusze mają możliwość wyboru między systemem monistycznym a systemem dualistycznym struktury organizacyjnej spółki.

64 Ze względu na transparentność reguł dotyczących stosowania bądź nie przez spółki rekomendacji dotyczących wynagrodzenia członków organów spółki należy negatywnie ocenić odrzucenie, w Preambule Dobrych Praktyk, reguły „przestrzegaj lub wyjaśnij”, na rzecz niejasnego wskazania, że rekomendacje zawarte w części I Dobrych Praktyk „wyrażają tendencje w zakresie właściwego sposobu układania relacji wewnętrznych i relacji spółek giełdowych z ich otoczeniem i z tego względu podobnie jak zasady objęte częściami II, III i IV są przedmiotem corocznych sprawozdań dotyczących postępowania w zakresie przestrzegania zasad ładu korporacyjnego, sporządzanych przez spółki giełdowe".

65 Zob. poniższe uwagi dotyczące relacji prawnej pomiędzy pkt 1 lit. h) Załącznika II zalecenia 2005/162 a art. $386 \S 1$ k.s.h. Ponadto, przykładowo w polskich regulacjach nie wprowadzono ograniczeń w przyznawaniu opcji na akcje, co postuluje unijny prawodawca, szerzej A. Opalski, Europejskie prawo spółek..., op. cit., s. 354. 
na jego osąd". ${ }^{66}$ Dodatkowo w motywie siódmym zalecenia 2005/162 podkreślono, że „niezależność należy rozumieć jako brak istotnej sprzeczności interesów; w tym kontekście należy zwrócić szczególną uwagę na zagrożenia, jakie mogą wynikać $\mathrm{z}$ faktu, że przedstawiciel w radzie dyrektorów ma ścisłe powiązania z konkurencją spółki”.

W załączniku II do zalecenia 2005/162 wymieniono kryteria, jakim odpowiada „Profil niezależnego dyrektora niewykonawczego lub dyrektora będącego członkiem rady nadzorczej”. Przy czym to wyliczenie nie jest wyczerpujące ${ }^{67} \mathrm{i}$ w każdym z państw członkowskich można je doprecyzować bądź rozszerzyć lub zawęzić. Dobre Praktyki rozszerzają jedynie zakres pkt 1 lit. b) Załącznika II zalecenia 2005/162, zgodnie z którym przesłankę niezależności spełnia osoba, która „nie jest pracownikiem spółki lub spółki stowarzyszonej; nie była w takiej sytuacji w ciągu ostatnich trzech lat, z wyjątkiem sytuacji, kiedy dyrektor niewykonawczy lub będący członkiem rady nadzorczej nie należy do kadry kierowniczej wysokiego szczebla lub został wybrany do rady (nadzorczej) w kontekście systemu przedstawicielstwa pracowniczego uznanego prawem i przewidującego odpowiednią ochronę przed niesłusznym zwolnieniem i innymi formami niesprawiedliwego traktowania". Na podstawie pkt III. 6 zdanie 3 i 4 Dobrych Praktyk ,niezależnie od postanowień pkt b) wyżej wymienionego Załącznika osoba będąca pracownikiem spółki, podmiotu zależnego lub podmiotu stowarzyszonego nie może być uznana za spełniającą kryteria niezależności, o których mowa w tym Załączniku. Ponadto, za powiązanie z akcjonariuszem wykluczające przymiot niezależności członka rady nadzorczej w rozumieniu niniejszej zasady rozumie się rzeczywiste $\mathrm{i}$ istotne powiązanie $\mathrm{z}$ akcjonariuszem mającym prawo do wykonywania 5\% i więcej ogólnej liczby głosów na walnym zgromadzeniu". Natomiast do pozostałych kryteriów niezależności nie odnoszą się, co ze względu na ich nieprecyzyjne ujęcie w Załączniku II zalecenia 2005/162 może budzić kontrowersje. Przykładowo powstaje wątpliwość odnośnie stosowania pkt 1 lit. h) Załącznika II do zalecenia 2005/162. Przewiduje on, że wymóg „niezależności” spełnia osoba, która ,nie pełniła funkcji w radzie (nadzorczej) jako dyrektor niewykonawczy lub dyrektor będący członkiem rady nadzorczej dłużej niż przez trzy kadencje (lub dłużej niż 12 lat, kiedy prawo krajowe przewiduje bardzo krótki wymiar normalnych kadencji)”. Przepis art. $386 \S 1$ k.s.h. określa jedynie maksymalną długość kadencji członka rady nadzorczej, która „nie może być dłuższa niż pięć lat”. W tym zakresie spółki mają autonomię i oczywiście mogą powoływać członków rady nadzorczej na okres krótszy niż pięć lat. Czy w takiej sytuacji należy uznać, że

66 G. Ferrarini, N. Moloney, M.C. Ungureanu, Executive Remuneration in Crisis: A Critical Assessment of Reforms in Europe, Journal of Corporate Law Studies 2010, s. 22.

67 Zgodnie z pkt. 1 załącznika II do zalecenia 2005/162 „wyczerpujące wyliczenie wszystkich zagrożeń dla niezależności dyrektorów nie jest możliwe; stosunki lub okoliczności przesądzające o tym mogą różnić się w poszczególnych państwach członkowskich i spółkach; zasady (...) w tym zakresie mogą ewoluować z czasem. (...) W tym kontekście na szczeblu krajowym należy przyjąć szereg kryteriów do stosowania przez radę (nadzorczą). Kryteria te (...) wymagają dostosowania do uwarunkowań krajowych (...). 
polskie prawo przewiduje „bardzo krótki wymiar normalnych kadencji”? Powstaje również pytanie, czy w przypadku, gdy członek rady nadzorczej zostanie powołany na cztery kadencje, których łączna długość wyniesie ponad 12 lat to straci automatycznie przymiot „niezależność” w rozumieniu zalecenia 2005/162, nawet gdy spełnia inne kryteria? Ponadto, jak należy kwalifikować sytuację, w której członek rady nadzorczej zostanie powołany na cztery kadencje, których łączna długość nie przekroczy 12 lat? I wreszcie wątpliwości powstają odnośnie okoliczności, czy te kadencje wskazane w pkt 1 lit. h) Załącznika II zalecenia 2005/162 powinny następować po sobie i czy przykładowo roczna przerwa spowoduje, że kolejne powołanie do pełnienia funkcji członka rady nadzorczej będzie traktowane jako ,nowe” na potrzeby interpretacji tej wytycznej? Pozostawienie wyłącznie spółkom odpowiedzi na te pytania może prowadzić do niezrealizowania celu zalecenia 2005/162.

Pomijając szczegółową analizę innych kryteriów niezależności ${ }^{68}$ należy uznać, że w przypadku spółek notowanych na GPW wobec braku odpowiedniej kompleksowej regulacji w Dobrych Praktykach, to same spółki będą decydowały, jakie kryteria niezależności członka organu spółki należy przyjąć. ${ }^{69}$ Należy wskazać, że zgodnie z pkt 13.2 zdanie 3 zalecenia 2005/162 to rozstrzygnięcie, tzn. spełnienie jakich wymogów przesądza o posiadaniu cechy niezależności, zasadniczo leży w gestii rady nadzorczej. ${ }^{70}$ Taka regulacja może powodować pewne wątpliwości, ponieważ to członkowie rady będą sami decydować, jakie kryteria niezależności, wymienione w załączniku II do zalecenia 2005/162, spełniają. Powyższe rozwiązanie może być potencjalnym źródłem konfliktu interesów. Z jednej strony kryteria niezależności mogą być interpretowane liberalnie. Przykładowo zgodnie z pkt. 1 lit. e) Załącznika II zalecenia 2005/162 jedno założeń „,niezależności” brzmi: „osoba nie utrzymuje obecnie ani nie utrzymywała w ciągu ostatniego roku znaczących stosunków handlowych ze spółką lub spółką stowarzyszoną". Spółka ma autonomię w interpretacji zakresu sformułowania ,znaczące stosunki handlowe". ${ }^{71} \mathrm{Z}$ drugiej strony mogą być one interpretowane nadmiernie rygorystycznie uniemożliwiając udział osobom, które byłyby pożądane w składzie rady nadzorczej ze względu na interes danej spółki z powodu swojej wiedzy i doświadczenia jako niespełniające w ocenie

Zob. szerzej K. Oplustil, Niezależni członkowie rady nadzorczej (administrującej) jako instrument wzmocnienia ładu korporacyjnego w spółkach publicznych, (w:) M. Cejmer, J. Napierała, T. Sójka (red.), Europejskie prawo spółek, Corporate governance, t. III, Kraków 2006, s. 380 i n.

69 Przy czym zwłaszcza w systemie dualistycznym spełnienie wybranych kryteriów może nieprowadzić do osiągnięcia celów założonych unijnymi regulacjami.

70 Rada nadzorcza może nawet stwierdzić, że mimo spełnienia przez dyrektora wszystkich określonych na szczeblu krajowym kryteriów oceny niezależności, danej osoby nie można uznać za niezależną w świetle szczególnych okoliczności dotyczących jej lub spółki; i odwrotnie (pkt 13.2 zdanie 3 zalecenia 2005/162).

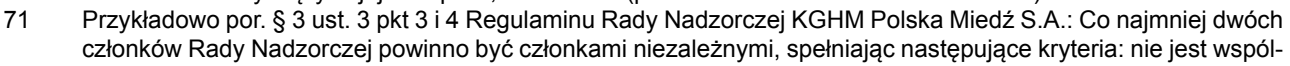
nikiem lub akcjonariuszem dysponującym $5 \%$ lub większą liczbą głosów na Walnym Zgromadzeniu Spółki lub Zgromadzeniu Wspólników albo Walnym Zgromadzeniu podmiotu powiązanego i nie jest członkiem rady nadzorczej lub zarządu lub pracownikiem podmiotu dysponującego $5 \%$ lub większą liczbą głosów na Walnym Zgromadzeniu Spółki lub Zgromadzeniu Wspólników albo Walnym Zgromadzeniu podmiotu powiązanego; http://www. kghm.pl/_files/File/2012/Rada\%20Nadzorcza/RN\%20nowy\%20regulamihn.pdf 
rady jednego z kryteriów niezależności. ${ }^{72} \mathrm{~W}$ tej sytuacji można byłoby rozważyć, czy takie kryteria, wobec braku stosownych rekomendacji w Dobrych Praktykach, zawrzeć w statucie spółki lub jednym z jej regulaminów wewnętrznych. ${ }^{73}$

Ponadto, wobec niesprecyzowanych jednoznacznie kryteriów w systemie dualistycznym można wątpić w pełną efektywność takiego środka, jakim jest „niezależność" członka rady nadzorczej. ${ }^{74}$ Należy wskazać, że instytucja niezależnych członków organu spółki wywodząca się z systemu anglosaskiego jest uzasadniona w systemie monistycznym, natomiast budzi ona pewne wątpliwości w systemie dualistycznym. ${ }^{75}$ Co więcej, posługiwanie się kryterium niezależności w uregulowanym przepisami k.s.h. systemie dualistycznym może prowadzić do wniosku, że $\mathrm{w}$ ramach rady nadzorczej istnieją dwie kategorie jej członków, tj. zależni i niezależni. ${ }^{76} \mathrm{~W}$ świetle przepisów k.s.h. takie twierdzenie jest nieuprawnione.

Analizując zagadnienie wynagrodzenia członków organów spółki akcyjnej należy też zwrócić uwagę na pkt III. 8 Dobrych Praktyk, w którym odesłano w zakresie zadań i funkcjonowania komitetów działających w radzie nadzorczej do stosowania zalecenia 2005/162. W spółce akcyjnej, a dokładnie w ramach organu, jakim jest rada nadzorcza powinny funkcjonować komitety, ${ }^{77}$ tj. komitet audytu, komitet ds. wynagrodzeń oraz komitet ds. nominacji. ${ }^{78} \mathrm{~W}$ zakresie polityki wynagrodzeń zalecenia Komisji przewidują utworzenie komitetu (komisji) ds. wynagrodzeń. ${ }^{79}$ Zgodnie z pkt. 6.1 zdanie 2 zalecenia 2005/162 rolą komisji ds. wynagrodzeń jest usprawnienie prac rady nadzorczej przez zapewnienie, aby decyzje były podejmowane po należytym rozpatrzeniu sprawy oraz pomoc w organizowaniu prac dla zapewnienia, aby decyzje podejmowane przez radę były wolne od istotnych sprzeczności interesów. ${ }^{80}$

72 A. Opalski, Niezależni członkowie rady nadzorczej, PPH 2005, nr 6, s. 13.

$73 \quad Z$ analizy dokumentów spółek notowanych na WIG 20 wynika, że takie definicje zawarte są przeważnie w statucie spółki lub regulaminie jej rady nadzorczej. Przykładowo definicja pojęcia „niezależność” została zawarta w $\S$ 14 pkt 5 Statutu Banku Polska Kasa Opieki Spółka Akcyjna, http://www.pekao.com.pl/binsource/f/78/11/bin_P1K04fd1458d168d40007811,BINFILE,PL,1,40,0/Tekst_jednolity_Statutu_Banku_18.06.2013.pdf

74 Na brak zależności między obecnością niezależnych członków rady a wielkością wynagrodzeń wypłaconych członkom zarządu zwraca uwagę A. Słomka-Gołębiowska (Rola komitetu wynagrodzeń w bankach w Polsce, zif. wzr.pl/pim/2013_2_6_21.pdf, s. 306). Na podstawie przeprowadzonych badań A. Słomka-Gołębiowska dowiodła, że na wysokość wynagrodzenia członków zarządu nie wpływa liczba niezależnych członków rady nadzorczej. $Z$ badań A. Słomki-Gołębiowskiej wynika również, że jedynie obecność niezależnego członka rady na stanowisku przewodniczącego komitetu wiąże się ze zmniejszeniem wynagrodzenia kadry zarządzającej. G. Ferrarini, N. Moloney, M.C. Ungureanu, Executive Remuneration in Crisis..., op. cit., s. 23.

$76 \quad$ Na takie zagrożenie wskazuje K. Oplustli, Instrumenty nadzoru..., op. cit., s. 433-434.

77 Tworzenie komitetów z zasady nie ma na celu wyłączenia rozważanych spraw z kompetencji samej rady nadzorczej, która zachowuje pełną odpowiedzialność za decyzje podejmowane w jej sferze kompetencji (pkt 6.1 zdanie 3 zalecenia 2005/162).

78 W doktrynie trafnie przyjmuje się, że komitety zostały umieszczone w strukturze wewnętrznej rady nadzorczej, tak m.in. M. Michalski, Spółka akcyjna, pod red. A. Kidyby, Warszawa 2010, s. 50.

79 Z raportu Deloitte „Współczesna rada nadzorcza 2012” wynika, że 1/3 badanych spółek ustanowiła komitet wynagrodzeń lub nominacji i wynagrodzeń; www.gpw.pl/biblioteka-gpw-pobierz?gpwl_id=84\&gpwlf_id=93.

80 Trafnie wskazuje A. Malarewicz, że członkowie komitetu lub komisji działającej w ramach rady nadzorczej nie mogą „podjąć uchwały w zastępstwie rady, te bowiem podejmuje rada jako organ spółki, a nie jej poszczególni członkowie" (A. Malarewicz, Spółka akcyjna, (w:) T. Mróz, M. Stec (red.), Prawo gospodarcze prywatne, Warszawa 2012, s. 347. 
Na marginesie należy wskazać, że zasady ładu korporacyjnego odnoszące się do spółek notowanych na NewConnect przewidują jeszcze węższy zakres regulacji odnoszących się do wynagrodzeń członków organów spółek. Na podstawie pkt. 9.1

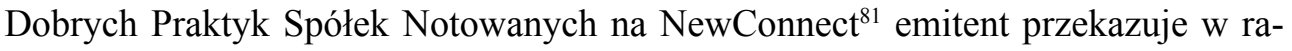
porcie rocznym: informację na temat łącznej wysokości wynagrodzeń wszystkich członków zarządu i rady nadzorczej. ${ }^{82}$

5. Analiza problematyki wynagrodzeń członków spółek akcyjnych ukazuje dwoistość tego zagadnienia. $Z$ jednej strony w przepisach k.s.h. trafnie sformułowano w sposób fragmentaryczny tę materię pozostawiając szeroką autonomię regulacyjną spółce w jej statucie bądź regulaminach jej organów. Niewątpliwie w wolnorynkowej gospodarce spółka akcyjna i akcjonariusze powinni mieć możliwość dowolnego i indywidualnego określania elementów składowych i wysokości wynagrodzeń członków jej organów. Zasada autonomii spółki w zakresie ustalania wynagrodzeń członków jej organów jest również uznawana na poziomie unijnym. $Z$ motywu 3 zlecenia 2009/385 wynika, że ,jakkolwiek forma, struktura i poziom wynagrodzeń dyrektorów w dalszym ciągu pozostaje zasadniczo w kompetencji spółki, jej akcjonariuszy, a w stosownych przypadkach również przedstawicieli pracowników, zdaniem Komisji zachodzi konieczność wprowadzenia dodatkowych reguł dotyczących struktury wynagrodzeń dyrektorów przyjętej przez daną spółkę w ramach polityki wynagrodzeń oraz procedury ustalania wynagrodzeń i nadzoru nad tą procedurą".

Z drugiej strony brak szczegółowych wytycznych w zakresie wynagrodzeń członków organów spółek akcyjnych może prowadzić do nadużyć. ${ }^{83} \mathrm{Z}$ przedstawionych powyżej uwag wynika, że w związku z fragmentarycznymi regulacjami k.s.h. i co do zasady odesłaniem w wielu kwestiach przez rekomendacje Dobrych Praktyk do unijnych zaleceń istnieje swoista luka dotycząca instytucjonalnych zabezpieczeń oraz wiążących wytycznych co do kształtu treści decyzji dotyczących wynagrodzeń członków organów spółek. Dlatego w obecnym stanie prawnym decyzje dotyczące wynagrodzenia członków zarządu i rady nadzorczej spółki akcyjnej powinny być oceniane przede wszystkim w świetle zasady słuszności, a zwłaszcza klauzuli dobrych obyczajów, która wyznacza granice autonomii woli stron i swobody umów. ${ }^{84}$ W ten sposób mogą być niwelowane ewentualne nieprawidłowości czy nadużycia. ${ }^{85}$ Właśnie dobre obyczaje znacząco wpływają na transparentność i uczciwość decyzji dotyczących wynagrodzeń członków organów spółek akcyjnych.

\footnotetext{
81 Obecnie obowiązują one w brzmieniu nadanym Uchwałą nr 293/2010 Zarządu Giełdy Papierów Wartościowych w Warszawie S.A. $z$ dnia 31 marca $2010 \mathrm{r}$.

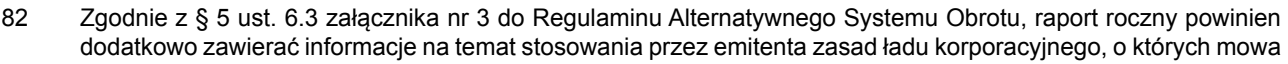
w „Dobrych Praktykach Spółek Notowanych na NewConnect”.

83 W piśmiennictwie podkreśla się rolę instytucjonalnych zabezpieczeń i odpowiednich procedur oraz stworzenie wytycznych co do kształtu wynagrodzeń, A. Opalski, Europejskie prawo spółek..., op. cit., s. 343.

84 Por. art. $353^{1}$ k.c.

85 Por. przywoływane postanowienie SA w Lublinie z 26.6.2012 r., I Acz 609/12.
} 
Jak już przedstawiono zakres pojęcia „dobre obyczaje” na gruncie prawa handlowego jest różnorodnie interpretowany. Wydaje się, że wąskie rozumienie tego terminu ograniczające się do uczciwości kupieckiej w relacjach z innymi uczestnikami obrotu gospodarczego niepotrzebnie go zawęża. Pojęcie „dobre obyczaje” należy odnosić także do stosunków wewnętrznych w spółce, w tym przyzwoitości i uczciwości w relacjach pomiędzy akcjonariuszami.

W przypadku spółek akcyjnych notowanych na GPW powinny być stosowane dobre obyczaje dotyczące wynagrodzeń członków organów zawarte w Dobrych Praktykach. Jednakże to zagadnienie zostało w Dobrych Praktykach uregulowane nieprecyzyjnie i w dużej mierze poprzez odesłania do unijnych uregulowań zawartych głównie w zaleceniach 2004/913 i 2009/385. Podstawowymi celami tych zaleceń są zapewnienie: przejrzystości praktyk w sferze wynagrodzeń oraz kontroli akcjonariuszy nad polityką wynagrodzeń, a także efektywnego i niezależnego nadzoru sprawowanego przez organy niewykonawcze ( $\mathrm{tj}$. w systemie dualistycznym: radę nadzorczą) poprzez udzielenie komitetowi ds. wynagrodzeń co najmniej głosu doradczego. Stosowanie przez spółki notowane na GPW szczegółowych unijnych rekomendacji może powodować szereg problemów. Wynikają one m.in. z ogólnych sformułowań zawartych w analizowanych zaleceniach, w których starano się uwzględnić całą paletę regulacji obowiązujących w poszczególnych państwach członkowskich, co ze swej istoty spowodowało ogólnikowość poszczególnych wytycznych bądź ich alternatywny charakter. Dodatkową trudność w stosowaniu wskazanych unijnych zaleceń powoduje okoliczność, że odnoszą się one zarówno do monistycznego, jak i dualistycznego systemu organizacji spółki akcyjnej. Co więcej wydaje się, że podstawą rozwiązań prawnych przyjętych w omówionych unijnych aktach prawnych jest system monistyczny, w którym wiele uprawnień przysługuje akcjonariuszom, a które w systemie dualistycznym zwykle należą do rady nadzorczej. ${ }^{86} \mathrm{Ze}$ względu na odmienne w tym zakresie rozwiązania w przypadku systemu dualistycznego i monistycznego pewne trudności może spowodować samodzielna interpretacja przez spółki wytycznych płynących z tych zaleceń.

$\mathrm{Z}$ rozważań zawartych $\mathrm{w}$ niniejszym opracowaniu wynika, że w przepisach k.s.h. nie zostały określone szczegółowe reguły dotyczące polityki spółki w zakresie wynagrodzeń członków zarządu i rady nadzorczej. Przepisy te nie przesądzają również, kto jest uprawniony do określania wynagrodzenia członków organów spółki akcyjnej. Natomiast Dobre Praktyki mają ograniczony zakres podmiotowy, a ponadto rekomendacje dotyczące wynagrodzeń członków rad nadzorczych są, oględnie mówiąc, nieprecyzyjne.$^{87}$ Wobec powyższego wydaje się, że ze względu na transparentność i bezpieczeństwo obrotu (w tym ochronę akcjonariuszy mniejszościowych)

86 M. Cejmer, Zalecenia Komisji w sprawie wynagrodzeń dyrektorów..., op. cit., s. 466.

87 Ta „nieprecyzyjność” odnosi się do m.in. merytorycznych rozwiązań, systemu odesłań do unijnych zaleceń, jak i sposobu określenia skutków prawnych poprzez m.in. niejasne stosowanie wobec części I Dobrych Praktyk zasady „przestrzegaj lub wyjaśnij”. 
można byłoby rozważyć przyjęcie, zgodnie z zasadą słuszności, jednolitego bezpośredniego odwołania do dobrych obyczajów w przepisach k.s.h. dotyczących wynagrodzeń członków organów spółki akcyjnej. Proponowana treść art. $378 \S 1$ k.s.h. poszerzona byłaby o zdanie drugie: „Wynagrodzenie członków zarządu powinno być określone zgodnie z dobrymi obyczajami”. Natomiast w odniesieniu do wynagrodzenia rady nadzorczej art. $392 \S 1$ zd. 2 k.s.h. przewidywałby: „Wynagrodzenie określa, zgodnie z dobrymi obyczajami, statut lub uchwała walnego zgromadzenia”. Wydaje się, że powyższe regulacje wpłynęłyby znacząco na transparentność i uczciwość w stosowaniu korporacyjnych reguł dotyczących tak wrażliwej materii, jaką są wynagrodzenia członków organów spółek akcyjnych. 


\section{THE INFLUENCE OF THE PRINCIPLE OF EQUITY ON THE FORMATION OF THE RULES DEFINING THE REMUNERATION OF MEMBERS OF GOVERNING BODIES IN JOINT-STOCK COMPANIES (SELECTED PROBLEMS)}

The system of remuneration can be a cause of serious conflicts between managers and stockholders, this including minority stockholders who have a lesser influence on the appointment of a company's governing bodies. Analysis of the provisions of the Act of 15 September 2000, the Commercial Companies Code governing the remuneration of members of the management board and supervisory board, showed that within its scope legal controls are fragmentary, giving the company broad autonomy. Yet this autonomy is not of absolute nature and the company is obliged to comply with the principles of law, this including the principle of equity.

In this article, the author analyses in detail one of the basic instruments for introducing the principle of equity which is the clause of good practice. The Commercial Companies Code does not specify how the term "good practice" should be understood. Therefore the author discusses opinions presented in jurisdiction as well as the stance of the doctrine; she also proposes her concept in this respect. In this article, a detailed analysis of the good practice applied in the case of jointstock companies is made, predominantly those regulated in the Good Practice of Companies Listed on WSE. The analysis also concerned its conformity with the European Union law in scope of remuneration policy.

Keywords: good practice, Good Practice of Companies Listed on WSE, jointstock company, remuneration of members of governing bodies in joint-stock companies, management board, supervisory board, principle of equity 